\title{
CHEMICAL GEOLOGY
}

\author{
(including Isotope Geoscience)
}

\section{Official Journal of the European Association for Geochemistry}

Honorary Editor:

W.S. Fyfe

\section{Advisory Editor: \\ A.C. Lasaga}

Editors-in-Chief:

R. Alexander, University of

Technology, School of Applied

Chemistry, G.P.O. Box U 1987, Perth, W.A. 6001, Australia,

C.J. Allègre, Institut de Physique du Globe, Université Pierre et Marie Curie, 4 Place Jussieu, Paris Cédex 05 , F-75230 France

N.T. Arndt, Université de Rennes, Institut de Géologie, Campus de Beaulieu, Avenue de Général Leclerc, Rennes Cédex, F-35042 France

M.J. Bickle, University of Cambridge, Department of Earth Sciences, Downing Street, Cambridge CB2 3EQ, UK

S.L. Brantley, Pennsylvania State University, University Park, PA, USA

E.B. Watson, Rensselaer Polytechnic Institute,

Department of Geology, West Hall, Troy, NY 12180-3590, USA

Editor-in-Chief ISOTOPE GEOSCIENCE SECTION:

P. Deines, Pennsylvania State University, 503 Deike Building, University Park, PA 16802, USA

\section{AIMS AND SCOPE}

Chemical Geology is devoted to providing rapid publication of original articles in the ever widening field of organic and inorganic geochemistry. Both long and short articles dealing with data from the Earth and other planets are accepted. The journal's aim is to cover the field of chemical geology in the broadest possible sense, including: low temperature geochemistry, organic/petroleum geochemistry, inorganic geochemistry, analytical techniques, isotope studies, environmental geochemistry, and experimental petrology and geochemistry.

Chemical Geology has been chosen by the European Association for Geochemistry as its official publication. However, the journal itself continues to be fully international in its outlook - a policy reflected by a team of Editors, whose high scientific standing and internationality ensures that Chemical Geology attracts contributions from the scientific community worldwide.

From 1993 Chemical Geology and Isotope Geoscience merge to form ONE journal, with a single volume numbering system to simplify cataloguing, archiving and citing. The title Isotope Geoscience now also appears on the cover of Chemical Geology. Isotope Geoscience papers are now published as part of the Chemical Geology issues - in the subsection /sotope Geoscience. However, these

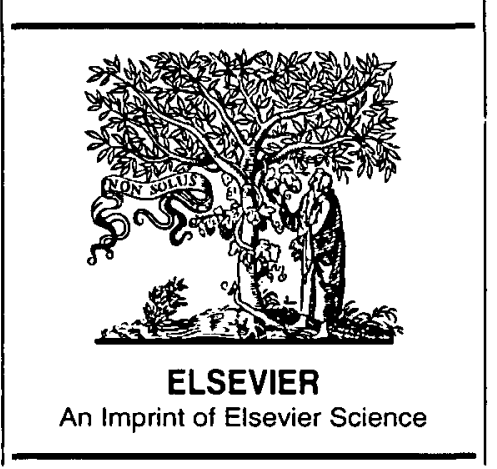

papers continue to be under the Editorial expertise of the existing /sotope Geoscience Editor and Editorial Board, thus ensuring optimal quality of the published material.

The Isotope Geoscience subsection contains original contributions and review articles dealing with experimental studies, analytical techniques and instrumentation and theoretical concepts of isotope geology and radiochemistry. All aspects of isotope geoscience and radiochemistry fall within the journal's scope including: stable isotope studies; radiogenic isotope studies; and radiochemical studies.

\section{ABSTRACTED/NDEXED IN}

AGl's Bibliography \& Index of Geology, Bulletin Signalétique, Chemical Abstracts, Current Contents, ESRISAT, Geo Abstracts, Mineralogical Abstracts,

PASCALCNRS, Petroleum Abstracts.

1995 SUBSCRIPTION DATA

Volumes $117-125$ (in 36 issues)

Subscription price:

Dfl. 3447.00 (US\$1814.00)

incl. postage

ISSN 0009-2541

\section{ELSEVIER SCIENCE B.V.}

Order Fulfilment Department

P.O. Box 211

1000 AE Amsterdam

The Netherlands

In the USA \& Canada:

Elsevier Journal Information Center P.O.Box 945

New York, NY 10159-0945

Dutch Guilder (Dfl.) price quoted applies worldwide, except in the Americas (North, Central and South America). US Dollar (US\$) price quoted applies in the Americas only. Customers in the European

Community should add the appropriate VAT rate applicable in their country to the price. 


\section{Earth Sciences}

\section{Co-Editors}

Y. Kolodny, The Hebrew University of Jerusalem

Z. Lewy, Geological Survey of Israel.

Israel Journal of Earth Sciences publishes regionally-oriented research, reviews and short communications across the broad spectrum of the Earth Sciences - from geology, geomorphology, and geochemistry to studies on paleontology, oceanography, hydrology, and hydrogeology.

Israel Journal of Earth Sciences is the primary forum for studies of the Middle Eastern and Eastern Mediterranean regions, including the Dead Sea, Red Sea, and Rift Valley areas. The Journal also covers broader topics of interest to the whole earth sciences community.

\section{Abstracted/Indexed in:}

American Geological Institute Bibliography and Index of Geology, BIOSIS, CAB Database, Chemical Abstracts, Current Contents, INSPEC Database, IBZ International Bibliography, Geographical Abstracts, Geological Abstracts, Science Citation Index.

Istael Journal of Earth Sciences - ISSN 0021-2164 • 4 issues per year - Volume $44(1995) \cdot$ Institutional rate US $\$ 160$ - Personal rate ${ }^{\circ}$ US $\$ 80$

\section{Order form}

Please enter my subscription to Israel Journal of Earth Sciences. Vol. 44 (4 issues), 1995. ISSN 0021-2164.

口 Institutional - US $\$ 160 \square$ Personal $^{\circ}$-US $\$ 80$ (mtes include ainnail)

$\square$ Send me the Morkeckai Magaritz Issue:- @ $\$ 85$.

Israel Journal of Earth Sciences, Volume 43, Nos. 3-4, 1994.

$\square$ Send me a free sample copy $\square$ Send a pro forma invoice.

- I enclose a check for $\$$ (To Laser Pages Publishing (1992) Ltd)

$\square$ Debit my credit card for $\$$
$\square$ Visa
¿ MasterCard
๑ EuroCard

Card \# Expiration Date

Signature Date

Name Telephone

Address City

Country/State Zip

-Available to those whose library subscribes, or who pay by personal check or credit card. cup/geo/01/95

Return to: Marketing Dept., Laser Pages Publishing (1992) Ltd., P.O. Box 50257, Jerusalem 91502, Israel, or FAX to 9722818782 .

\section{Mordeckai Magaritz Issue}

Intemational contributions to this double issue cover the following topics:-

- stable isotope geochemistry

- hydrology

- environmental geology

- archaeological geochemistry.

Contents include:-

Carbon isotopes, dissolved oxygen, and the carbonate system in the northem Gulf of Aquaba(Elat) (A. Shemeshet al.) • Carbonand oxygen isotope tracers of submarine hydrocarbon emissions: Northern Gulf of Mexico (P. Alaron) - Phosphorus cycling and phosphonus sources in Lake Kinneret: Tracing by oxygen isotopes in phosphate (D. Markel et al.) - The chloride content in pore water of Lake Kinneret sediments (M. Stiller) • Carbon cycle in the upper Danube and its tributaries: $\delta^{13} \mathrm{C}_{\text {pac }}$ constraints (F. Pauellek \& J. Veizer) - Survey of factors controlling the stable isotope ratios in precipitation in the Great Lakes region, USA (M.V. Machavaram $\measuredangle R V$. Krishnamurthy) $\bullet$ A rapidand precise methodof oxygen isotope analysis of biogenic phosphate (J.R. O'Neil et al.) • New tritium data in waters of the Dead Sea area $(Y$. Yechieliet al.) • Evidence for isotopicequilibrium in stalagmites from caves in adry region: Jerusalem, Israel (A. Frumkin et al.) • Boron isotopes in Heletz-Kokhavoilfield brines, the Coastal Plain, Israel (A Vengosh et al.) • An analysis of two automatic history-matching procedures for estimation of subsurface reservoirproperties (B. Berkowitz \& S.M. Farouq Ali) • Estimating theturnovertime of groundwater reservoirs by the helium-3/tritium method in the era ofdeclining atmospheric tritium levels: Opportunitiesandlimitations in the time bracket 1990-2000 (I. Carmi bJ.R. Gat)•Mass extinctionsin thelast 300 million years: One impact and seven flood basalts? (V. Courtillot) $\bullet$ Siliceous aggregates from prehistoricwoodash(S. Schiegl et al.) - The dynamic chemistry of transition metals in the troposphere (S.O. Pehkonen et al.) - Identification of formation process and source of biogenic gas seeps (I.R. Kaplan).

Israel Journal of Earth Sciences Volume 43, Nos. 3-4 • 182 pp • Jan 1995 - ONLY US \$85 inc. airmail. 
$b$

Blackwell Science

ACN 004901562
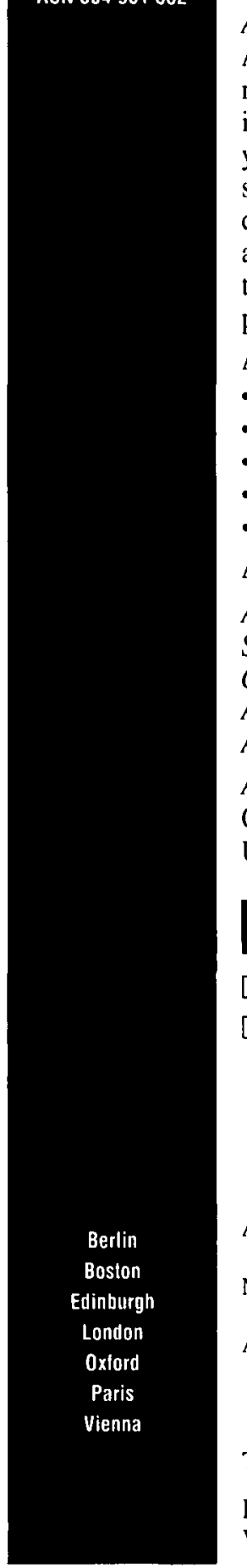

\section{AUSTRALIAN JOURNAL OF EARTH SCIENCES}

\section{Editor-in-Chief A. E. Cockbain Assistant Editor J. Backhouse}

Australian Journal of Earth Sciences is the official journal of the Geological Society of Australia. The journal publishes research papers and significant review articles on topics ranging from those of a purely theoretical and experimental nature to those of more general interest to geoscientists. A special thematic issue is published each year, featuring a selection of papers devoted to a particular area of earth science: these are frequently the outcome of specialist international conferences held in the Australasian region. Short geological notes are also published on new developments in the geosciences. In addition, the journal publishes critical discussion of research papers recently published in the journal.

AIMS AND SCOPE

- offers high quality, peer reviewed papers

- encourages international communication

- covers all aspects of earth sciences

- focuses on the Australasian, Western Pacific and South-East Asian regions

- provides thematic issues with international coverage

\section{ABstracting AND INDEXING}

Australian Journal of Earth Sciences is covered by AESIS, CAB International, Cambridge Scientific Abstracts, Current Awareness in Biological Sciences, Current Contents/Physical, Chemical and Earth Sciences, Geoarchive, Geobase, Geological Abstracts, Geotechnical Abstracts, Meteorological and Geoastrophysical Abstracts, Petroleum Abstracts, Research Alert, Science Citation Index, Scisearch, University Microfilms and Zoological Record.

Australian Journal of Earth Sciences is published bimonthly in February, April, June, August, October and December. The 1995 (Volume 42) subscription rates are Aus $\$ 297.00$ (Australasia), US $\$ 349.00$ and Aus $\$ 499.00$ (elsewhere) including surface air lifted.

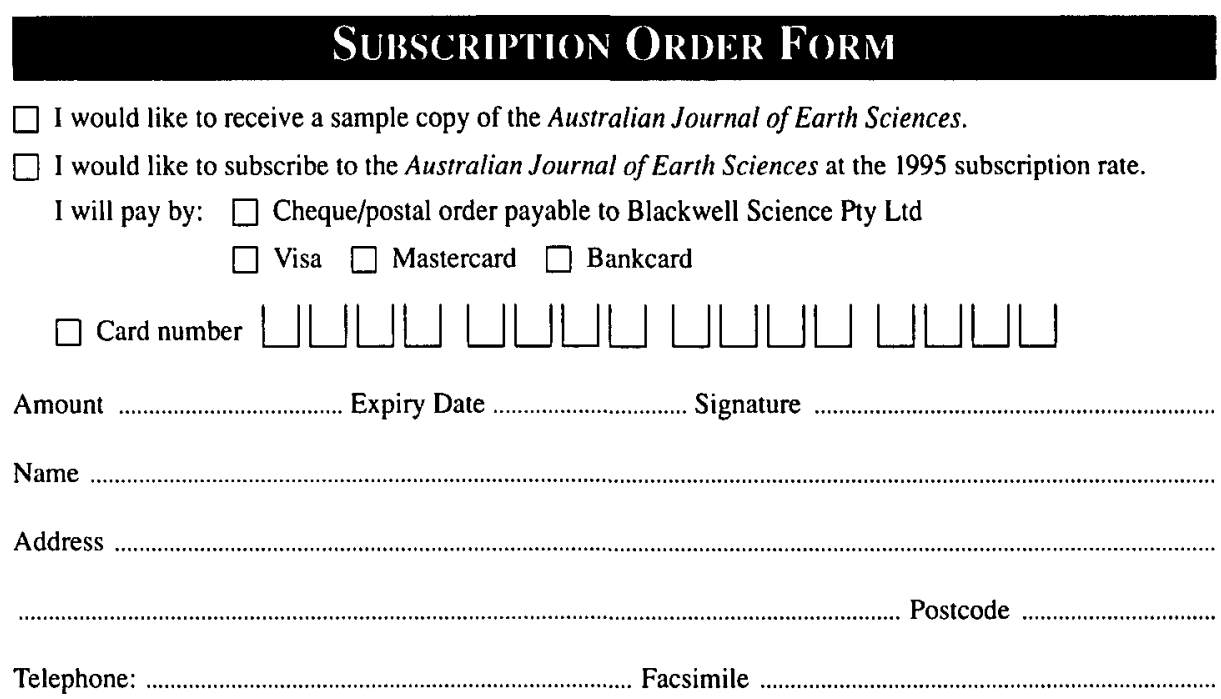

Post or fax to: Blackwell Science Pty Ltd, 54 University Street (PO Box 378), Carlton South, Vic. 3053 Australia. Telephone (61 3) 3470300 Facsimile (61 3) 3475001 


\section{NOTES FOR CONTRIBUTORS}

Contributions for publication, accompanied by a covering letter, should be addressed to The Editors, Geological Magazine, Department of Earth Sciences, Downing Street, Cambridge CB2 $3 E Q$, England, or may be submitted through a member of the Editorial Advisory Board (addresses inside front cover). Rapid Communications should be clearly marked as such on the envelope. Submission implies that the manuscript has not been published previously nor currently submitted for publication elsewhere. Upon acceptance of a manuscript, the author will be asked to transfer copyright to the publisher.

All contributions, whether articles, correspondence or reviews, must be sent in triplicate and typed on one side of the paper, with wide margins and double-line spacing throughout, with a font size no smaller than 12 point Times equivalent. Any minor corrections should be made neatly in the typescript, leaving the margins clear. The author may provide the final version of the contribution on disk (PC or Mac format, 'Word' or 'Wordperfect') in addition to the paper copies. Contributions should follow the general style of papers in recent issues of the Magazine. The author is invited to nominate up to five possible referees, who will not necessarily be used.

Articles must be accompanied by a brief, informative rather than indicative, abstract. Headings should be set out clearly but not underlined. Primary headings should be in lower case, at margin, with arabic numeral; subheadings should be numbered 2.a., 2.b., etc., and tertiary headings 2.a.1., 2.a.2. No cross-references should be given by page number, but 'above' and 'below' should be used with the section specified, e.g. Section 2.a.2. The SI system of units should be used. Avoid acronyms. The author should mark in the margin of the manuscript where figures and tables may be inserted. References to points in larger works should, where possible, quote the page reference, e.g. Ager, 1981, p. 102. Authors alone are responsible for the correctness of their references. Use 'et al.' in the text only when there are four or more authors.

Rapid Communications should follow the style of articles and must be no more than four printed pages of the Magazine (approximately 5000 word-equivalents) including an abstract of no more than 100 words. These contributions will be dealt with by a streamlined schedule and should appear within six months from receipt. To mee this schedule, authors will be required to make revisions with minimal delay.

Discussions of papers which have already appeared in the Magazine are welcomed, subject to the four-page limit.

Tables should be typed with double-line spacing on sheets separate from the running text. Each table must have a caption that will make the data in the table intelligible without reference to the text.

Mlustrations should be submitted at final publication size, and separate parts should be labelled with lower-case letters, e.g. Figure $6 a, b, c$. The Author's name and figure number should be clearly marked on the back of each piece of artwork. Please draft figures for printing at either single column $(80 \mathrm{~mm}$ ) or double column (169 $\mathrm{mm}$ ) width. The height of figure can vary in either width up to full print area height $(240 \mathrm{~mm})$. Illustrations should have scale bars, not ' $\times 40$ '. Redrafting may be required by the editors if major savings in print area can be achieved without loss of information. Detailed maps or multiple logs may well require a whole page and the size of the lettering should match the necessary reduction. Where necessary break a figure into two facing pages; folding figures will not be accepted. Landscape figures should have no lettering upside down on the final printed page. Avoid where possible gross disparities in lettering size on the drawing. Boxes of ornament should be explained within the figure, not in the caption. When designing ornament for computer-drawn line diagrams, use the ranges $10-60 \%$ tint and 60-120 dpi (= lpi) for best results. Figures composed of photographs should be glossy prints presented at publication scale. Each component part should be named with a lower-case letter and given a scale bar. Photographic artwork is numbered as part of the sequence of figures, not as separate plates. The Magazine will be able to publish a limited number of free colour plates each year; the editors will decide which plates to accept on their scientific merit. Authors submitting colour plates are asked to give detailed reasons why colour is necessary. Duplicates of illustrations should be sent, and may be prints or, preferably, photocopies reduced to final size. Figure captions must be typed with double-line spacing on sheets separate from the running text.

References must be double-spaced and spelt out in full, e.g.

BROOKS, M. \& JAMES, D. G. 1975. The geological results of seismic refraction surveys in the Bristol Channel, 1970-73. Journal of the Geological Society, London 131, 163-82.

Books should be cited as

AGER, D. V. 1981. The Nature of the Stratigraphical Record, 2nd ed. London: Macmillan, $122 \mathrm{pp}$.

BotT, M. H. P. 1973. The evolution of the Atlantic north of the Faroe Islands. In Implications of Continental Drift to the Earth Sciences, vol. 1 (eds D. H. Tarling and S. N. Runcorn), pp. 175-89. London, New York: Academic Press.

Unpublished work should normally be referred to in the text in parentheses as, for example, 'private communication' or 'unpub. Ph.D. thesis, Univ. London, 1988', and not included in the reference list unless in the press.

Fifty offprints of each paper will be provided free of charge. Additional offprints may be purchased according to a set scale of charges if ordered when the proofs are returned. 


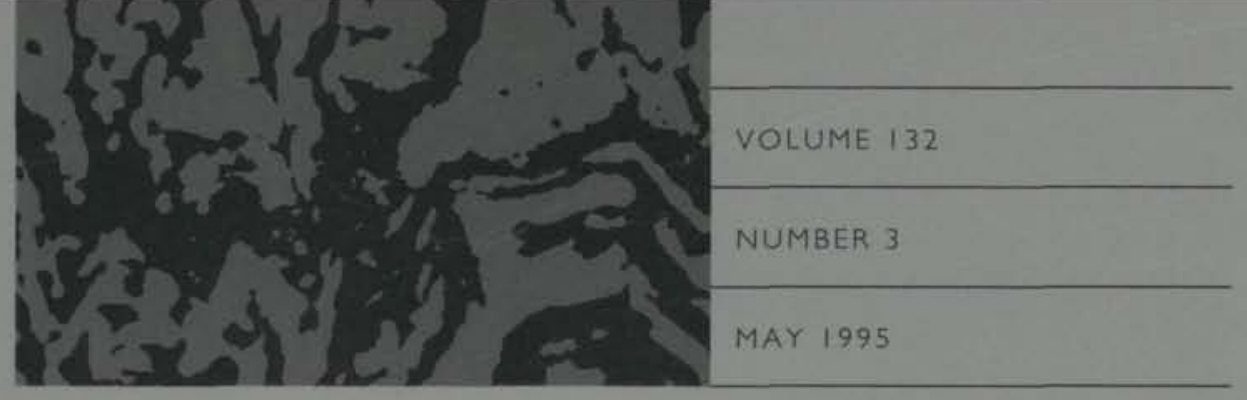

\section{Geological Magazine}

\section{CONTENTS}

First report of Pan-African $\mathrm{Sm}-\mathrm{Nd}$ and $\mathrm{Rb}-\mathrm{Sr}$ mineral isochron ages from regional charnockites of southern India

UNNIKRISHNAN-WARRIER, C., SANTOSH, M. \& YOSHIDA, M.

253-260

Open-system magma chamber process in the Freetown Complex of

Sierra Leone: evidence from Zone 3

CHALOKWU, C. I. \& SENEY, P. J.

A deep-marine ichnofaunal assemblage from Llandovery strata of the Welsh Basin, west Wales, UK

ORR, P. J.

Geochemistry and tectonic significance of augen gneisses from the southern Menderes Massif (west Turkey)

BOZKURT, E., WINCHESTER, J. A. \& PARK, R. G.

Isotope studies of granitoids from the Bangenhuk Formation, $\mathrm{Ny}$

Friesland Caledonides, Svalbard

JOHANSSON, A., GEE, D. G., BJÖRKLUND, L. \& WITT-NILSSON, P.

303-320

Geochemistry of bimodal amphibolitic-felsic gneiss complexes from eastern Massif Central, France

BRIAND, B., BOUCHARDON, J.-L., OUALI, H., PIBOULE, M. \& CAPIEZ, P.

Geochemical character of Neoproterozoic volcanic rocks in southwest

Wales

BEVINS, R. E., PHARAOH, T, C., COPE, J. C. W. \& BREWER, T. S.

$339-349$

DISCUSSION

Discussion on the Ny Friesland Orogen, Spitsbergen

Comment: G. M. Manby \& N. Lyberis

$351-354$

Reply: W. B. Harland

$354-356$

REVIEWS

$357-363$

PUBLICATIONS RECEIVED

Printed in Great Britain by the University Press, Cambridge 